Article

\title{
Feasibility Analysis of the Sustainability of the Tres Palos Coastal Lagoon: A Multifactorial Approach
}

\author{
Ana I. Casarrubias-Jaimez ${ }^{1}$, Ana Laura Juárez-López ${ }^{1}$, José Luis Rosas-Acevedo ${ }^{1}$, Maximino Reyes-Umaña ${ }^{1}$, \\ América Libertad Rodríguez-Herrera ${ }^{1}$ and Fernando Ramos-Quintana ${ }^{2, *}$ \\ 1 Regional Development Science Center, Universidad Autónoma de Guerrero, Acapulco 39640, Mexico; \\ anajaimez@uagro.mx (A.I.C.-J.); 05197@uagro.mx (A.L.J.-L.); 05722@uagro.mx (J.L.R.-A.); \\ 11471@uagro.mx (M.R.-U.); 12585@uagro.mx (A.L.R.-H.) \\ 2 Biodiversity and Conservation Research Center, Universidad Autónoma del Estado de Morelos, \\ Cuernavaca 62209, Mexico \\ * Correspondence: ramosfernando747@gmail.com
}

check for

updates

Citation: Casarrubias-Jaimez, A.I.; Juárez-López, A.L.; Rosas-Acevedo, J.L.; Reyes-Umaña, M.;

Rodríguez-Herrera, A.L.;

Ramos-Quintana, F. Feasibility

Analysis of the Sustainability of the Tres Palos Coastal Lagoon: A

Multifactorial Approach.

Sustainability 2021, 13, 537.

https://doi.org//10.3390/su13020537

Received: 11 December 2020

Accepted: 6 January 2021

Published: 8 January 2021

Publisher's Note: MDPI stays neutral with regard to jurisdictional clai$\mathrm{ms}$ in published maps and institutional affiliations.

Copyright: $\odot 2021$ by the authors. Licensee MDPI, Basel, Switzerland. This article is an open access article distributed under the terms and conditions of the Creative Commons Attribution (CC BY) license (https:// creativecommons.org/licenses/by/ $4.0 /)$.

\begin{abstract}
We studied the cultural eutrophication process assessments of coastal lagoons by considering sociopolitical, socioeconomic, demographic, technological, and cultural factors, which represent indirect drivers exerting effects on the eutrophication process, causing changes on the trophic status. Multifactorial interactions in eutrophication processes make understanding their complex dynamics difficult, leading to unreliable assessments and, consequently, to unsustainable management actions. This, in turn, hinders the feasibility of coastal lagoon sustainability. We propose a method based on the evaluation of pathways derived from a multifactorial network, which represents the eutrophication process, with the aim of determining the feasibility of the sustainability of the Tres Palos coastal lagoon. Our findings revealed that most of the evaluations of relationships belonging to pathways were unfeasible due to reasons such as: there was no evidence of the existence of public policies, technological skills, and cultural factors; there was a lack of data related to human settlements around the lagoon and river, industrial waste, agricultural practices, and tourism. The preceding shortcomings hinder the feasibility of coastal lagoon sustainability under study. We suggest that assessments of cultural eutrophication processes that overlook sociopolitical, socioeconomic, technological, and cultural factors are limited and inadequate for supporting the feasibility of sustainable coastal lagoons.
\end{abstract}

Keywords: coastal lagoons; cultural eutrophication; multifactorial approach; network analysis; sustainability

\section{Introduction}

Coastal lagoons (CLs) are considered productive ecosystems, providing food from fisheries, fauna and plants, construction materials from trees and reeds, freshwater, and recreational areas, among others, for the benefit of human wellbeing [1-5].

However, human disturbances have caused changes in coastal lagoons [6], where population growth and changes in land use, among other things, have played a significant role in the impact on these ecosystems [7]. The decline of services provided by ecosystems has accelerated across the world due to population increase and consumption products [8-10]. For instance, due to changes in consumer behavior, waste production has grown ten times more than population growth during the past century [11]. Likewise, population increase has caused solid waste to increase [11-16]. The preceding examples show how the relationship between population increase and economic factors without regulation influence waste production increase, which in turn damages the quality state of environmental regions and ecosystems.

The eutrophication process has been classified as the main problem in marine ecosystems. Eutrophication is identified as a process that causes the growth of plants due to the 
enrichment of nutrients disposed into a waterbody, which has been considered one of the main problems in coastal ecosystems [17-21]. The eutrophication process may occur either through natural causes or as a result of human activities and/or events, such as human settlements, which generate activities that damage the trophic state of water bodies [18,22-29]. The concept of cultural eutrophication has been incorporated as a process mainly derived from human activities, such as deforestation [30], the use of fertilizers in agriculture [31], and nitrogen emissions [32], among the most important, all of which contribute to trophic state changes in water bodies. The cultural term associated with the eutrophication process obviously leads to tourist activities because CLs provide natural landscapes enjoyed by humans [8,33-36].

Thus, based on the preceding facts, we show that CLs offer environmental, social, and economic services for human wellbeing [2,37-42]. Due to this fact, CLs are permanently threatened by human activities, thus exerting pressures on the quality state of these water bodies, where the increase in human settlements and tourist developments are considered as significant indirect drive factors that contribute to the vulnerability of these water bodies to a considerable extent [43-45]. The reduction in nitrogen $(\mathrm{N})$ and phosphorus $(\mathrm{P})$ is proposed to obtain adequate levels of water quality on the Mediterranean coast, where the cultural eutrophication became a serious problem [46].

The trophic state is the relative flow rate of carbon in the trophic web, which is commonly used to classify the biotic productivity of the aquatic ecosystems. The following aspects are related to the trophic state of coastal lagoons:

- The human activities generate direct drivers that commonly damage the quality of waterbodies [47];

- The energy availability for the food web, thus defining the community integrity and the ecosystem functionality, which varies from unproductive, intermediate productive, and highly productive [48];

- The conditions of vulnerability in the CLs, such as eutrophication, which is caused by the presence of organic matter, thus directly affecting the water quality of the CLs [49-52];

- $\quad$ The effects caused by chemical factors on trophic states are regularly characterized by green pigment found in most algae caused by chlorophyll, growth of algae and aquatic plants caused by phosphorous and nitrogen as nutrients necessary for the clearness of water transparency;

- The four trophic states and their most important characteristics:

(1) Oligotrophic state: clear water, few aquatic plants, fish, wildlife, and a sandy bottom;

(2) Mesotrophic state: moderate level of biological productivity, clear water, and aquatic plants;

(3) Eutrophic state: high level of biological productivity that supports big quantities of fish and wildlife;

(4) Hypertrophic state: highest level of biological productivity that may support important quantities of fish and wildlife; the water body may have an abundance of aquatic plants, and very low water clarity.

The conceptual frameworks in the study of the eutrophication processes play a very important role, because they may cope with the inherent complexity of such processes by building structures that facilitate the understanding of the dynamic brought about by multifactorial interactions [53].

Conceptual frameworks may provide developers with tools to support the management of the complex systems associated with eutrophication problems. One of these conceptual frameworks is the DPSIR [54], where driving-force (D) exerts effects on pressure (P) factors, which in turn cause changes on the state $(S)$ of the system, thus causing impacts (I) that require a response $(R)$ from society to mitigate the effects on the system under study.

DPSIR has been applied to the study of waterbodies. For example, an environmental pollution assessment of the Ebrié lagoon (Côte d'Ivoire), where agricultural activities and the production of human waste were the main drivers of pollution [55]; the assessment 
of sustainability in coastal domains was carried out by using the DPSIR framework combining natural and socioeconomic factors to implement public policies [56]; due to the fact that water consumption has increased as economic development has increased, and that industrial and agriculture pollutants have exerted important pressures on water resources, then a sustainability assessment of water resource management has been also required, using the DPSIR framework in China [57]; an integration of ecosystem services (ESs) and social benefits (SBs) with the DPSIR framework, named DPSIR-ES\&SB, for sustainable management of marine environments has been proposed [58]; in the context of a review of applications of the DPSIR framework related to social ecological systems (SESs) for coastal and estuarine systems, it is considered that DPSIR should be updated to become a useful management tool aimed to support the analysis and the identification of solutions to environmental problems [59]; the DPSIR framework served as a tool is used to understand coastal socio-ecological systems and identify drivers and pressures, which result in useful support for decision-makers in management tasks [53]; in order to discover the causes of the decline related to seagrass meadows, DPSIR was applied to identify driver, pressures, state and impacts in the Ria Aviero lagoon. The results provided by this study revealed that anthropogenic pressures were the main causes of such a decline [60]; the Ria de Aveiro (Portugal), Mar Menor (Spain), Tyligulskyi Liman (Ukraine), and Vistula Lagoon (Poland and Rusia) are four coastal lagoons selected within a Pan-European context to formulate a set of recommendations aimed at building an integrated and sustainable management system [61]. These coastal lagoons have a common characteristic: they have been submitted to severe anthropogenic stress, thus requiring protection to provide services in a sustainable way, which should be supported by adequate public policies. Anthropogenic factors, such as those derived from population increase, tourism, agriculture activities, and exploitation of natural resources, are important drivers that exert pressures on coastal lagoons. The understanding of the interaction between ecological and socioeconomic factors was a key aspect to generate public policies, which should be selected by decision-makers by taking into account specific needs for each coastal lagoon.

Certain conflicts related to the definition of driving forces and pressure factors emerge when the DPSIR framework is used to deal with environmental and ecosystem issues. DPSIR is a framework that hosts causal relationships, such as those where driving-forces cause effects on pressure factors to bring about changes in the environmental or ecosystem state. However, a debatable aspect associated with the DPSIR framework is related to some drivers that do not cause direct effects on pressure factors, but they do exert certain influences on pressure variables through other factors, thus causing effects on the environmental or ecosystem state. That is the case of sociopolitical, technological, and cultural factors that can be considered as indirect drivers that influence the variation of pressure factors that damage ecosystems. This weakness is related to the fact that the DPSIR structure does not deal with different levels of drivers [55]. Another important weakness related to the DPSIR framework is that it deals usually with unidirectional causal chains, which are associated commonly with linear behaviors, but this is not the case when we deal with complex systems, such as those related to environmental and ecological systems [55,62]. Despite the shortcomings mentioned above, the DPSIR supports the explanation and communication of research results in an accessible and meaningful way to decision makers and provides policy makers with meaningful explanations of the cause-effect relationships [63].

One of the contributions derived from the Millennium Ecosystem Assessment (MEA) report, which was focused on the analysis and assessment of ecosystem services that provide benefits to human wellbeing, was the proposal oriented to define the role of indirect and direct drivers. Indirect drivers are related to demographic, socioeconomic, sociopolitical, technological, and cultural factors [64-66]. Meanwhile, for the case of coastal lagoons, direct drivers are related to chemical components and solid waste disposal into the lagoon, which are produced at the level of the lagoon and the river that feeds the lagoon, among the most important. 
The final product of the eutrophication process is represented by quantities of nitrogen and phosphorous disposed of into the coastal lagoon, which are commonly used to assess the levels of their trophic state. However, other factors that exert influence on the eutrophication process are usually overlooked in the assessments. Such factors represent indirect drivers that exert influence on the eutrophication process which, in turn, affect quantitatively the direct drivers that exert direct effects on the trophic state of coastal lagoons. However, by involving interactions between multiple factors-in the study of the eutrophication process of coastal lagoons-it makes it difficult to understand the dynamics of such complex systems, thus leading to unreliable assessments and, consequently, to an inadequate selection of management actions aimed at improving the trophic state. This, in turn, hinders the feasibility of the development of coastal lagoon sustainability.

Two important aspects should be addressed when we deal with assessments of systems composed of multiple factors. The first aspect deals with the units associated with factors involved in the assessment, which commonly belong to different areas. The multiple factors derived from sociopolitical, socioeconomic, demographic, technological, and cultural domains have different units associated with them that should be measured to be assessed. We can illustrate this aspect through the following example: sociopolitical domains in eutrophication problems are mainly related to public policies that may or may not exist. In such a way, binary values may represent the existence or absence of a public policy. Chemical aspects represented by nitrogen and phosphorous that are disposed of into a waterbody can be represented by quantitative values such as "ppm $/ \mathrm{mm}^{3}$ ". Based on the fact that different units are associated with different factors, the assessment of multifactorial networks may be carried out by combining qualitative and quantitative values for the sake of improving the expressivity of the assessment and thus facilitating its interpretation. Meanwhile, the second aspect concerns the interactions between multiple direct and indirect drivers, which can be represented by a complex network, knowing that as the number of both indirect and/or direct factors increases the more complex dynamic networks may result, which in turn would become more difficult to understand, analyze and assess. These two problems are addressed in the section on methods.

We propose in this work a model based on multifactorial networks aimed at linking indirect and direct drivers through sequences of relationships that represent the eutrophication process resulting from human activities to changes of the trophic state of the waterbody under study. We introduce a structure represented by a novel classification of indirect and direct drivers, from which we build the multifactorial network. In order to facilitate the analysis and assessment of the eutrophication process, we have extracted pathways, from the network, associated with the lagoon and the river. Such pathways represent aspects of the eutrophication process.

A key issue addressed in this work is the feasibility assessment of the relationships belonging to the eutrophication process represented by the pathways related to the lagoon and to the river. In such a way that if the assessment of pathways is unfeasible, then the sustainability of the coastal lagoon is put at risk, because this reveals that important factors are not satisfied. Such factors may be: public policies do not exist or there is no evidence of their existence or their implementation or their performance; there is no evidence of environmental education programs; there is a lack of necessary technology that supports actions such as the treatment of solid wastes, among others; there are no data to measure the human settlements around the lagoon and the river during a considerable period of time, among other factors that may be quantified or qualified. Due to the fact that pathways are represented by sequences of relationships that link factors (indirect and/or direct factors), then the basic unit of evaluation will be the relationships belonging to pathways.

\section{Methods}

\subsection{Towards the Feasibility Analysis of Coastal Lagoon Sustainability}

Sustainable development of coastal lagoons requires adequate management systems to ensure conservation and sustainable use, which will result in improving human wellbeing. 
Thus, an essential condition to pave the way towards a sustainable ecosystem depends on the good performance of an adequate management system [64-66]. The construction of an ecosystem management system should be well underpinned to trace the way towards ecosystem sustainability. A conceptual framework based on a systems approach may guide the construction of the structure of a sustainable ecosystem management. This structure should be supported by a closed system within which an open system is included. Such a structure should help us take care of the following essential three steps: the understanding of the dynamics of a complex system that is based on the interactions between factors related to indirect and direct drivers (step 1), thus facilitating the assessment of the cultural eutrophication process that causes changes in the trophic state of the coastal lagoon (step 2), in such a way that both the understanding and the assessment of the eutrophication process become a key support for decision-making processes (step 3). The aim is to select adequate management actions to reduce the damages caused by the cultural eutrophication process. Management actions proposed by the decision-making process will be implemented, and their performance monitored and assessed. The monitoring and assessment of the management actions implemented (step 4) are the inputs to a feedback unit (step 5) that aims to propose corrections, modifications, and changes of the executed management actions. These last two steps (4 and 5 ) are combined with the open system to complete a closed system.

In particular, we deal in this work with step 1 and step 2 . The relationships between indirect and direct driver factors are used to build a network represented by a directed graph. The evaluation of relationships must be feasible; otherwise, the assessment step will not be achieved, and the purpose to pave the way towards attaining the ecosystem sustainability will be put at risk.

The relationships are composed of a node that causes effects or exerts influence on a second node, as shown by the following expression: $X \rightarrow Y$, where $X$ causes effects on $Y$ or $X$ exerts influence on $Y$. Node $X$ is called the effector node and $Y$ the receptor node. For instance, if $X$ represents the population increase and $Y$ the increase in human settlements around the lagoon, then we may conclude that $X$ has caused effects on $Y$. In this case, the relationship between $X$ and $Y$ should be evaluated using population data that are able to represent a period of time (a certain number of years) in order to prove that both populations have really increased. Otherwise, if there are no data to represent the increase in both variables during a period of time, then this relationship is unfeasible because of the unavailable data.

Other relationships can be composed of an existent public policy that aims to regulate human settlements around the lagoon. For example, $\mathrm{PP} \rightarrow \mathrm{HS}$, where PP represents a regulatory public policy and HS human settlements around the lagoon, which can be read as follows: the public policy (PP) causes the regulation of the human settlements (HS) around the lagoon. As we can see, this relationship can also be interpreted as a dependency relationship, because regular human settlements depend on the existence and implementation of public policy. What we have to highlight in this relationship is that if there is no public policy or data to prove the presence of human settlements around the lagoon, then this relationship fails, and it is not possible to validate its feasibility. Therefore, this relationship is unfeasible and hinders the evaluation of this important relationship.

We note that several types of relationships exist, for instance: cause-effect relationships, influence relationships, dependency relationships, among others.

Before analyzing the feasibility of the relationships between indirect and direct drivers that affect the eutrophication process, we aim to simplify the analysis of feasibility of the relationships related to the eutrophication process, for which we propose the following methods:

(1) The method for building the network, which contains the relationships, based on a reclassification of indirect and direct drivers;

(2) The method for building pathways, which are extracted from the network. A pathway is defined by a sequence of relationships that link indirect drivers with direct drivers. 
Pathways may have one or several initial nodes representing indirect drivers and just one final node representing a direct driver;

(3) Finally, a method based on the evaluation of relationships. The network is composed of simple and multiple relationships. We describe below the cases related to simple and multiple relationships:

- A simple relationship is represented by an effector factor and a receptor factor, as shown by the following expression: $\mathrm{X} \rightarrow \mathrm{Y}$, where $\mathrm{X}$ represents the effector and $\mathrm{Y}$ the receptor. For example, we can establish the following relationship: factor $\mathrm{X}$ causes effects on factor $\mathrm{Y}$.

- Multiple relationships take place when several effector factors exert effects on one receptor factor. That is, two or more than two effector factors may exert effects on one receptor factor.

- One effector factor exerts effects on two or more than two receptor factors.

\subsection{The Method to Build the Network}

The fact of building a network composed of relationships between multiple factors related to indirect and direct drivers will lead to a complex network that is very hard to interpret. We aim to facilitate the construction and interpretation of the processes to be represented in the network. In order to achieve this aim, we propose a method to build a classification system composed of several levels of indirect and direct drivers.

Depending on the complexity of the network, a certain number of levels of indirect and direct drivers may be defined. In order to achieve this, the following reasoning has been applied:

(i) The nodes representing human activities that may affect the cultural eutrophication processes, thus exerting influence on potential changes in the eutrophication process will be associated with indirect drivers.

(ii) The nodes representing actions or events related to the production of tangible and measurable elements such as quantities of nitrogen and phosphorous, which may change the trophic state of the lagoon, will be associated with subcategories of direct drivers. This will facilitate the following:

(1) The construction of a network structure that will be easier to interpret;

(2) The understanding of factors that influence the cultural eutrophication processes, which may change the trophic state of the lagoon;

(3) The analysis of relationships between factors that may hinder the feasibility of coastal lagoon sustainability.

Figure 1 shows the reclassification of indirect and direct drivers. Indirect Drivers-I belong to a general category from which more specific categories will be derived. The category represented by Indirect Drivers-II contains fewer abstract concepts, for example, human settlements, tourism, and industries at the level of the river that feed the lagoon with water, among others. A category that represents more specific concepts, from which we can distinguish events or situations that exert influence on direct drivers, is labeled as Indirect Drivers-III. Examples of this category are consumption products derived from tourism activities, the generation of consumption products by industries along the river (in the case of the Tres Palos Lagoon treated in this work we refer to beverage and building material industries), and the consumption of mangrove resources, among others.

The Direct Drivers-III category are activities that may generate chemical components which may cause trophic changes. Examples of these activities are agricultural practices that use nutrients and insecticides that in turn produce dangerous liquid and solid wastes. Direct Drivers-II represent sediments from the lagoon and/or river, and liquid and solid waste from the lagoon and/or river. Such sediments and wastes contain the chemical elements that are disposed directly into the lagoon (Direct Drivers-I), thus changing the trophic state of this waterbody. 


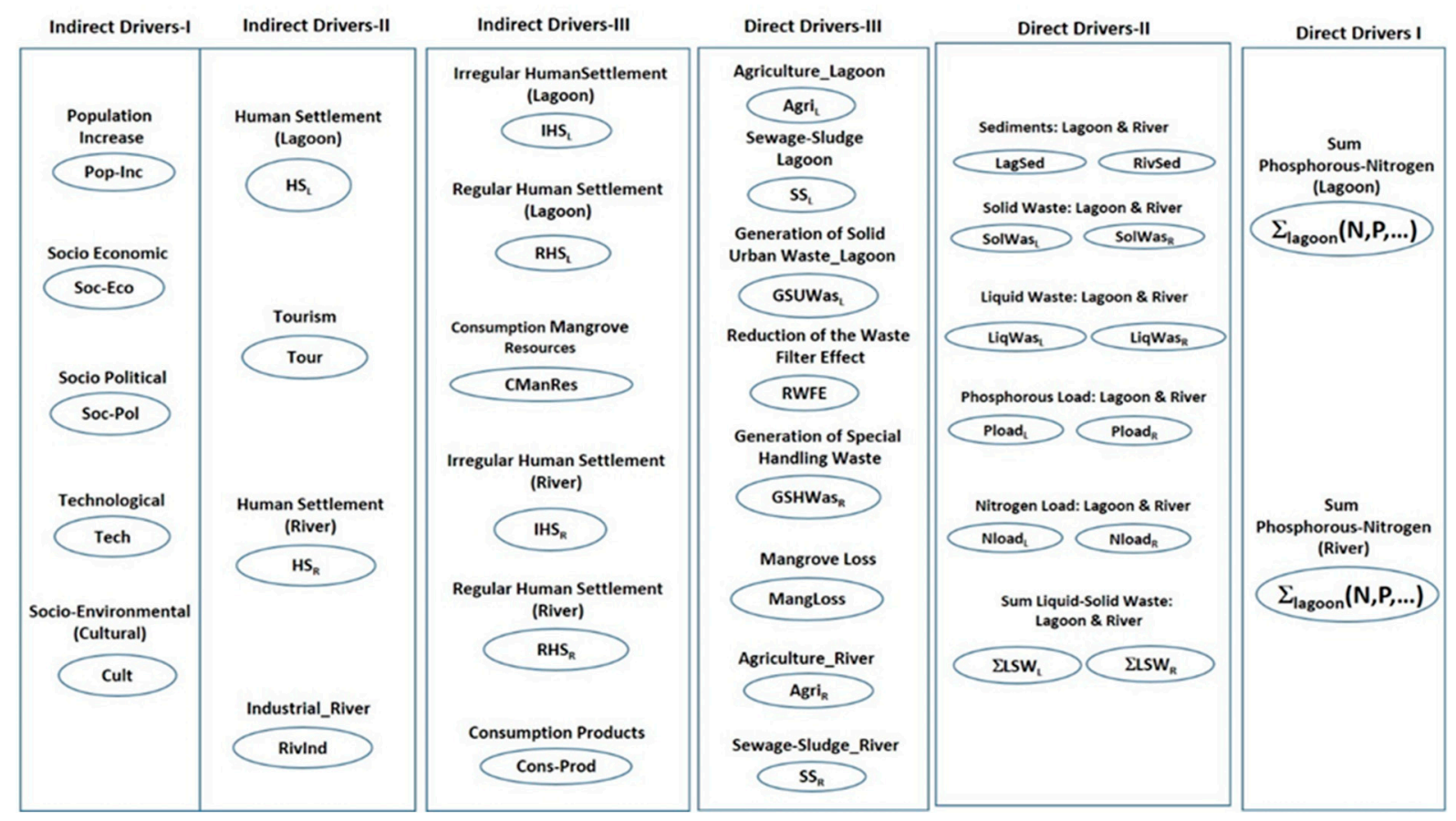

Figure 1. Reclassification of indirect and direct drivers.

As shown in Figure 1, due to the reclassification of categories related to indirect and direct drivers, the structure of the network has been simplified to improve the interpretation related to the influence of indirect drivers on direct drivers taking place during the eutrophication process. As expected, factors that represent indirect drivers would not be represented by physical or chemical tangible products that are disposed of into the lagoon; these factors are not easily measurable. On the contrary, elements belonging to the categories of direct drivers may be transformed into real nitrogen and phosphorous elements disposed of into the lagoon, thus they are easier to be measured.

The final network built by using the reclassification of direct and indirect drivers shown is shown in Figure 2 below.

\subsection{The Method to Build Pathways}

The main purpose of a pathway is to simplify the interpretation of relationship sequences that link indirect drivers with direct drivers. The number of pathways will be determined by the number of Direct Drivers-I. A pathway has just one node belonging to the category Direct Driver-I; it can have one or several initial nodes belonging to the category Indirect Drivers-I. A pathway is also composed of intermediate nodes, which may belong either to the indirect drivers or to the direct drivers.

We distinguish two pathways in Figure 2, one pathway related to the factors associated with the lagoon (with links or arcs in black) and one pathway related to the factors associated with the river (with links in green). In order to simplify the analysis of pathways, the following considerations should be taken into account:

(1) A relationship is defined by an effector and a receptor linked by a directed arc, as follows:

$X \rightarrow Y$, where $X$ takes the role of an effector and $Y$ is the receptor. The symbol " $\rightarrow$ " means a directed arc, where the direction is indicated by the arrow serving as a semantical meaning of the relationship, thus it should be respected.

(2) The nodes representing Indirect Drivers-I will be colored as follows: the population increase node in gray; the socioeconomic node in black; the sociopolitical node in red; the technological node in blue; the socio-environmental (culture) node in green. 
(3) The links from Indirect Drivers-I to other nodes belonging to Indirect Drivers-II and III are not explicitly drawn with a long line arc, which may bring about a complex web hard to handle. In order to cope with this problem, the colored node representing an Indirect Driver-I (an effector) is linked to the receptor node (an Indirect Driver-II or -III) with a short, directed line, as shown by several links depicted in Figure 2.

(4) The pathways are built starting at a selected Direct Driver-I of the network and then going backwards to the Indirect Drivers-I through the intermediate relationships.

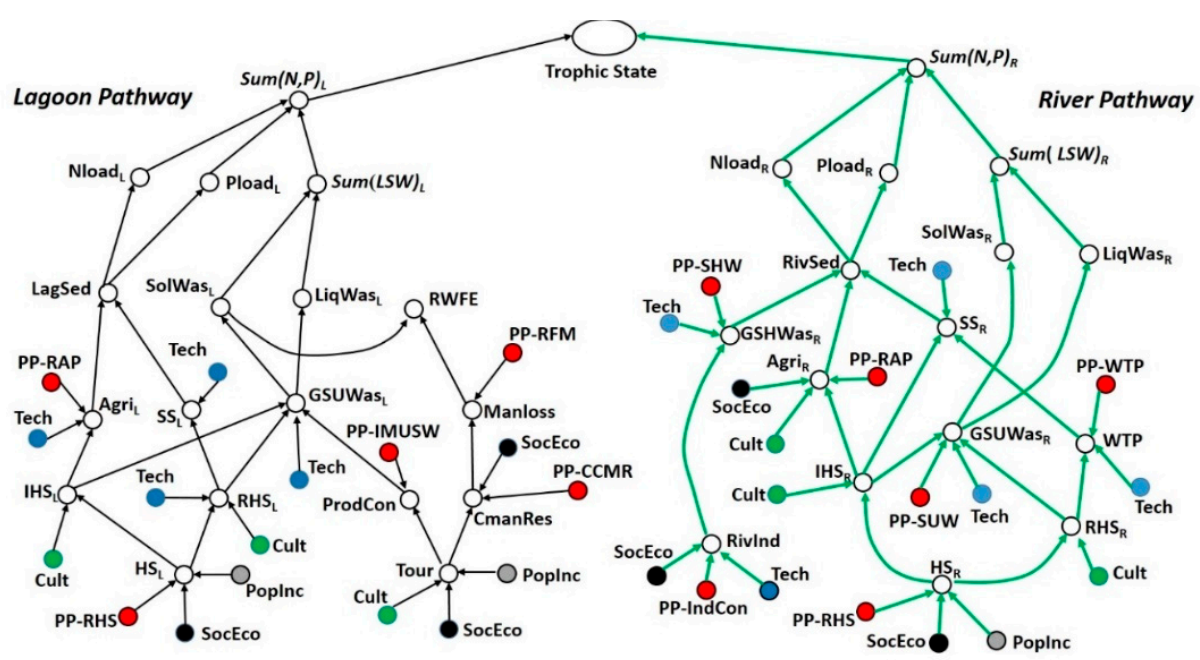

Figure 2. The complex network that represents indirect drivers that exert influence or effects on direct drivers that directly change the trophic state of the lagoon. (Acronyms related to the nodes depicted in Figure 2. Sum nitrogen and phosphorus from lagoon $=\operatorname{Sum}(\mathrm{N}, \mathrm{P})_{\mathrm{L}} ;$ nitrogen load from the lagoon $=$ NLoad $_{L} ;$ phosphorous load from the lagoon $=\operatorname{Pload}_{\mathrm{L}} ;$ sum of liquid and solid waste from lagoon $=$ Sum $\mathrm{LSW}_{\mathrm{L}} ;$ lagoon sediments $=$ LagSed; lagoon solid waste $=$ SolWas $_{\mathrm{L}} ;$ lagoon liquid waste $=\operatorname{LiqWas}_{\mathrm{L}}$; reduction in the waste filter effect $=$ RWFE; agriculture around the lagoon $=$ Agri $_{L}$; sediments around the lagoon $=\mathrm{SS}_{\mathrm{L}} ;$ generation of solid urban waste around the lagoon $=\mathrm{GSUWas}_{\mathrm{L}}$; mangrove loss = Manloss; irregular human settlements around the lagoon= $\mathrm{IHS}_{\mathrm{L}}$; regular human settlements around the lagoon $=\mathrm{RHS}_{\mathrm{L}}$; consumption of products = Cons-Prod; consumption of mangrove resources $=\mathrm{CManRes}$; human settlements around the lagoon $=\mathrm{HS}_{\mathrm{L}}$; tourism $=$ Tour; sum nitrogen and phosphorus from the river $=\operatorname{Sum}(\mathrm{N}, \mathrm{P})_{\mathrm{R}}$; nitrogen load from the river $=\mathrm{NLoad}_{\mathrm{R}}$; phosphorous load from the river $=$ Pload $_{\mathrm{R}}$; sum of liquid and solid waste from river $=$ Sum $(\mathrm{LSW})_{\mathrm{R}}$; river sediments $=$ RivSed; river solid waste $=$ SolWas $_{R}$; river liquid waste $=$ LiqWas $_{R}$; generation of special handling waste $=$ GSHWas $_{R}$; sewage sludge from the river $=\mathrm{SS}_{\mathrm{R}}$; agriculture around the river $=$ Agri $_{R}$; generation of solid urban waste $=$ GSUWas $_{R} ;$ wastewater treatment plants $=$ WTP; industry around the river = RivInd; regular human settlements around the river $=\mathrm{RHS}_{\mathrm{R}}$; irregular human settlements around the river $=\mathrm{IHS}_{\mathrm{R}}$; human settlements around the river $=\mathrm{HS}_{\mathrm{R}}$; public policies to regulate human settlements = PP-RHS; public policies to regulate agricultural practices = PP-RAP; public policies for the integral management or urban solid waste = PP-IMUSW; public policies to control the consumption of mangrove resources = PP-CCMR; public policies for the industrial control = PP-IndCon; public policies for the integral management of special handling waste = PP-IMSHW; public policies for wastewater treatment plants = PP-WTP; public policies for reforestation of mangrove $=$ PP-RFM.)

\subsection{The Method to Evaluate Relationships of the Pathways}

In this work we mainly deal with the feasibility of relationships belonging to pathways. The feasibility of relationships will be conditioned by the availability of essential elements or resources associated with the two components of a relationship. These resources are the availability of data of important factors and the existence of public policies, technological skills, and socio-environmental cultural programs. Thus, the feasibility of 
a relationship will fail if lacking the resources mentioned above. Obviously, such a relationship would be classified as unfeasible. Consequently, the pathway containing the unfeasible relationship is directly affected and, in turn, affects the feasibility conditions of coastal lagoon sustainability.

As already described, there are simple and multiple relationships. We use the concept of and-logic-gates to evaluate whether a relationship is feasible or unfeasible, in such a way that the two nodes of a relationship should have a true value to validate that the relationship is feasible. Otherwise, the relationship will be unfeasible. As already known, the two inputs of an and-logic-gate have to be true to obtain a true output value. Otherwise, the output value will be false. In the case of this work, one input represents the effector factor and the second one the receptor factor. We remember that a relationship is represented by the following expression: $X \rightarrow Y$, where $X$ is the effector factor and $Y$ the receptor factor. The expression is converted into an and-logic-gate. As mentioned before, $\mathrm{X}$ and $\mathrm{Y}$ may represent either indirect or direct drivers and their values may be either "existent" or "nonexistent" and either "data" or "lack of data". Here, "existent" and "data" are represented by " 1 " or "true" and "nonexistent" and "no data" are represented by " 0 " or "false", in the true table.

We introduce here an example of evaluation of a relationship using an and-logic-gate. Let us analyze the multiple relationship where Soc-Eco, PP-IndCon, and Tech are the effector factors and RivInd is the receptor factor. This multiple relationship is located in the river pathway. As shown in Figure 3, the graph that represents this multiple relationship is converted into a circuit composed of five and-logic-gates. Gate 1 represents the relationship (Soc-Eco $\rightarrow$ RivInd) and gate 2, the relationship (PP-IndCon $\rightarrow$ RivInd). The output of gate 1 and gate 2 become the inputs of gate 3 . Gate 4 represents the relationship (Tech $\rightarrow$ Rivind). The output of gate 3 and gate 4 become the inputs of gate 5 . The output of gate 5 will represent the result of the evaluation of this multiple relationship. Based on this representation, we may identify feasible and unfeasible relationships, where value " 1 " stands for feasible and " 0 " for unfeasible.

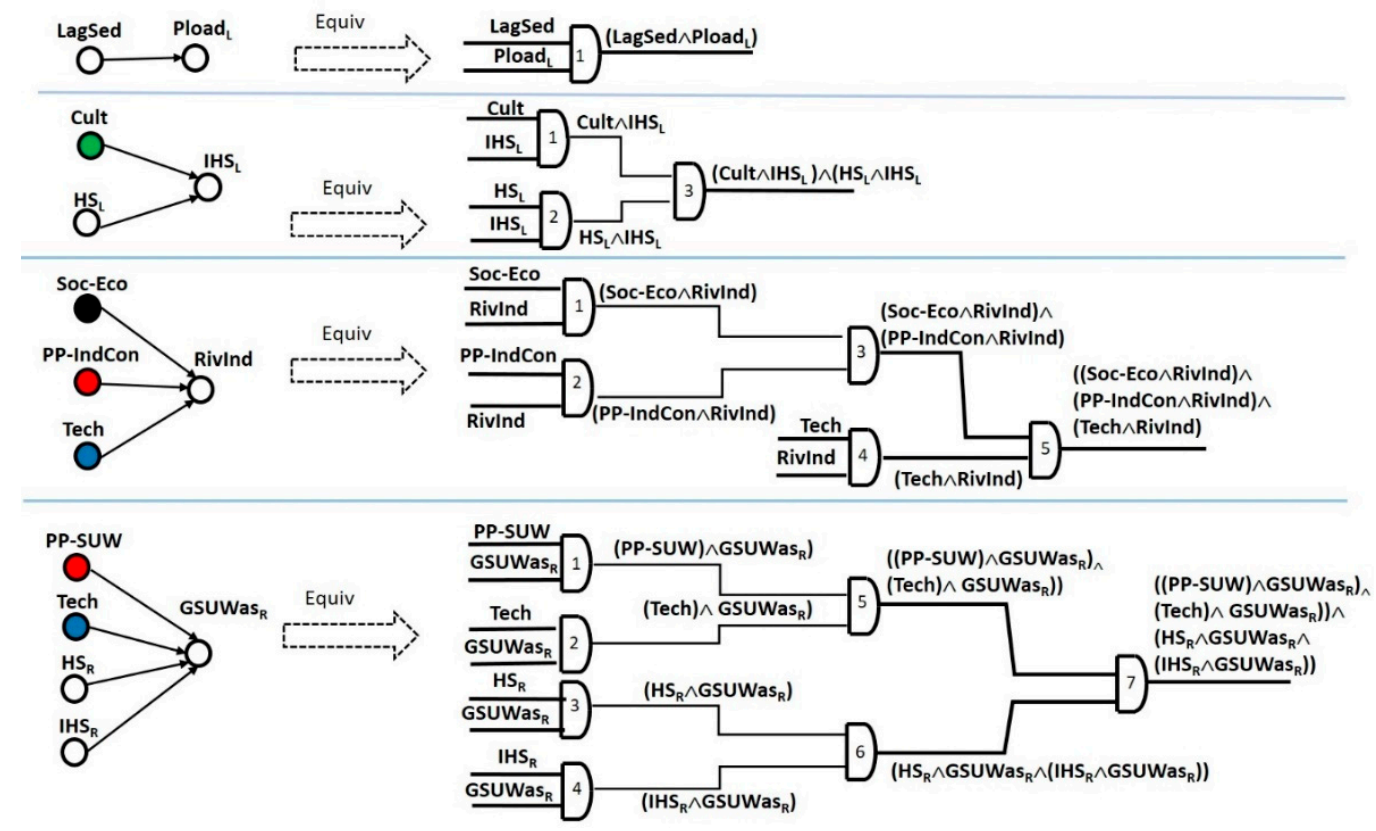

Figure 3. Simple and multiple relationships represented by graphs and their equivalence in and-logic-gates.

An example of an unfeasible relationship: we analyze the multiple relationship composed of the following simple relationships: (Cult $\left.\rightarrow \mathrm{IHS}_{\mathrm{L}}\right)$ and $\left(\mathrm{HS}_{\mathrm{L}} \rightarrow \mathrm{IHS}_{\mathrm{L}}\right)$. In this case, three and-logic-gates are used to represent these two relationships, as shown in Figure 3. The environmental education program (Cult) is related to the irregular human settlements. 
Thus, if there is evidence of the existence of the environmental education program, then the Cult variable will have the value of " 1 " or "true", otherwise, its value will be " 0 " or "false". Meanwhile, if there is available data during, at least, a period of time $\geq 10$ years, a value of " 1 " will be assigned to the variable that represents the irregular human settlements $\left(\mathrm{IHS}_{\mathrm{L}}\right.$ ). If not, its value will be " 0 ", which means "no data". In conclusion, if one of the variables of this relationship has a value of " 0 ", then this relationship is unfeasible.

The second relationship represented by the expression $\left(\mathrm{HS}_{\mathrm{L}} \rightarrow \mathrm{IHS}_{\mathrm{L}}\right.$ ) needs available data during a period of time $\geq 10$ years for both variables to be a feasible relationship. Otherwise, it will be an unfeasible relationship. Due to the fact that the value assigned to these two relationships is the input of the and-logic-gate number 3 (see Figure 3), then if one of them or both have a value of " 0 ", this multiple relationship will be labeled as unfeasible.

\section{Analysis of Results and Discussion}

\subsection{The Importance of the Understanding and Assessment of the Cultural Eutrophication Process}

We would like to remind and highlight that the main purpose of this work is to determine the feasibility of the sustainability of the Tres Palos coastal lagoon. As mentioned in the methods section, the sustainability of an ecosystem should be underpinned by an adequate ecosystem management system (EMS) [64,65]. We argue in this work that an adequate EMS that deals with multifactorial complex systems, such as coastal lagoons, should be supported by the three following steps: 1) the understanding of multifactorial interactions, which commonly bring about complex systems, which in turn are hard to understand; 2) the assessment of the cultural eutrophication processes, which are caused by multiple factors derived from anthropogenic activities. We consider that an assessment without understanding how the process works, from the causes to the effects, is an erroneous assessment unable to support the decision-making process; 3) the decisionmaking process to support the selection of adequate management actions. The decisionmaking process should be supported by the two preceding steps (understanding and assessment). Due to the fact that these three elements are a fundamental part of an environmental management system [64-66], then unsatisfactory performance of these steps has a direct effect on the feasibility of lagoon sustainability.

In this work, we have dealt mainly with the understanding and assessment steps as key basic aspects of the sustainability conditions in the coastal lagoon under study. As the results show, we have improved the understanding of the complex system by developing a new classification of indirect and direct drivers to facilitate the construction and interpretation of the network that represents the multifactorial interactions.

In addition, we have built pathways extracted from the network to facilitate the analysis and assessment of the cultural eutrophication process, divided into the river and the lagoon pathways. Due to the fact that a pathway is composed of a sequence of relationships between factors involved in the analysis, the assessment of a pathway is carried out through its relationships, which are classified in several types: cause-effect relationships, influence relationships, dependency relationships, among the most important.

\subsection{Feasibility Analysis of the Relationship Evaluations}

In this work, we conclude that an important aspect related to the sustainability of the coastal lagoon under study is to verify and/or validate whether the evaluations of the relationships of the multifactorial network are feasible or unfeasible. In such a way that if the evaluations of the relationships are unfeasible, then the evaluation of a pathway is unfeasible and, consequently, the evaluation of the network representing the multifactorial interactions is unfeasible. Thus, the second step (the assessment) cannot be performed or is unfeasible, which significantly weakens the intention of attaining conditions of sustainability. 


\subsection{The Conditions of an Evaluable Relationship}

A key aspect to be evaluated is the feasibility of a relationship. In such a way that a relationship is feasible if the following conditions are satisfied: (1) if the resources to individually evaluate the elements that compose the relationship are available; for example, data related to the human settlements around the lagoon or the existence of a public policy, among others; (2) if the relationship under evaluation makes sense from the point of view of its relevance to the purpose of the pathway. For example, if we establish the following relationship: the population increase (Pop-Inc) causes the increase in human settlements $\left(\mathrm{HS}_{\mathrm{L}}\right)$ around the lagoon, then, we consider that this relationship makes sense, and it is relevant for the purpose of a pathway associated with the cultural eutrophication process. In addition, if the data for the variables Pop-Inc and $\mathrm{HS}_{\mathrm{L}}$ are available, then the assessment of this relationship is feasible. On the contrary, the statement of the following relationship, "the population increase exerts influences in the increase of the quantity of water per second to be fed into the lagoon", does not make sense for the purpose of a pathway associated with the cultural eutrophication process. Thus, this relationship cannot be assessed and, consequently, is unfeasible. Another example of an unfeasible assessment is the next relationship: population increase (Pop-Inc) causes the increase in irregular human settlements around the lagoon. This relationship makes sense, but we would like to know whether the population data are available, during a period of time of more than 10 years, for both elements. In case both or one of the two data are not available, the assessment of this relationship is unfeasible, due to the lack of data.

\subsection{Results of the Feasibility of the Relationship Evaluations}

We show in Tables 1 and 2, the river-pathway relationships and the lagoon-pathway relationships, respectively. We show in these tables the relationships and their result as "Unfeasible" or "Feasible". We note that the five Indirect Drivers-I population increase (PopInc), socio-economic (Soc-Eco), socio-political (Soc-Pol), technological (Tech), and cultural (Cult)) may adopt two possible values: Nonexistent and Existent. An Indirect Driver-I with the value of "Nonexistent" means that there is no evidence that an action associated with this factor exists, or there is no formal way of proving that it exists. For instance, if a particular public policy is not formally documented in government communication offices (for instance, the Official Journal of the Federation or the Official Site of the State of Guerrero), then the value to be associated with this public policy will be "Nonexistent". Moreover, where public policy does exist, but it has not yet been implemented, the value associated with it will also be "Nonexistent", from a practical point of view. On the contrary, when an Indirect Driver-I has a value of "Existent", there is evidence that this factor exists or there is a formal manner of proving that it exists. The remaining factors should be evaluated by quantitative values, such as population increase during a certain period of time or tons of waste, etc. If there is no way of quantifying such variables due to the lack of, or missing or imprecise, data, then these variables will have the result labeled as "no data".

\subsection{Synthesis of Results of the Feasibility of Relationship Evaluations}

Table 1 (relationships of the Lagoon) shows 40 relationships, 18 of which have the effector factor classified as Indirect Driver-I. In just 3/18 relationships associated with Indirect Drivers-I, we were able to prove their existence or quantifiable data. Regarding the variables that can be quantified by data, just $3 / 19$ could be quantified. Finally, just $2 / 40$ relationships were feasible for evaluation and $38 / 40(95 \%)$ were unfeasible, due to the lack of, or missing or imprecise, data.

Meanwhile, Table 2 shows 38 relationships, 18 of which are related to Indirect DriversI factors playing the role of effector factors in their corresponding relationships. Just one relationship could be feasible: Soc-Eco $\rightarrow$ RivInd (the first relationship in Table 2). The remaining relationships (37/38) $(97 \%)$ are evaluated as "unfeasible", because either they are classified as nonexistent (in the case of Indirect Driver-I) or they are classified as "no-data" for the case of quantifiable factors, due to the lack of, or missing or imprecise, data. 
Table 1. Relationships of the lagoon pathway.

\begin{tabular}{|c|c|c|c|}
\hline Relationship & Observations & Relationship & Observations \\
\hline $\mathrm{SocEco} \rightarrow \mathrm{HS}_{\mathrm{L}}$ & $\begin{array}{l}\text { Unfeasible. Soc-Eco: Existent; } \\
\mathrm{HS}_{\mathrm{L}} \text { : no data }\end{array}$ & $\operatorname{Sum}(\mathrm{LSW})_{\mathrm{L}} \rightarrow \operatorname{Sum}(\mathrm{N}, \mathrm{P})_{\mathrm{L}}$ & $\begin{array}{l}\text { Unfeasible. Sum }(\mathrm{LSW})_{\mathrm{L}} \text { and } \\
\operatorname{Sum}(\mathrm{N}, \mathrm{P})_{\mathrm{L}}: \text { no data }\end{array}$ \\
\hline Pop-Inc $\rightarrow \mathrm{HS}_{\mathrm{L}}$ & Unfeasible. $\mathrm{HS}_{\mathrm{L}}$ : lack of data & $\mathrm{GSUW}_{\mathrm{L}} \rightarrow \mathrm{LiqWas}_{\mathrm{L}}$ & $\begin{array}{l}\text { Unfeasible. GSUW } \\
\text { LiqWas } \text { and } \\
\text { Liquata } \text { nodata }\end{array}$ \\
\hline $\mathrm{PP}-\mathrm{RHS} \rightarrow \mathrm{HS}_{\mathrm{L}}$ & $\begin{array}{l}\text { Unfeasible. PP-RHS: } \\
\text { nonexistent; } \mathrm{HS}_{\mathrm{L}}: \text { no data }\end{array}$ & $\operatorname{LiqWas}_{\mathrm{L}} \rightarrow \operatorname{Sum}(\mathrm{LSW})_{\mathrm{L}}$ & $\begin{array}{l}\text { Unfeasible. } \text { LiqWas }_{L} \text { and } \\
\text { Sum(LSW) })_{L} \text { : no data }\end{array}$ \\
\hline Cult $\rightarrow \mathrm{IHS}_{\mathrm{L}}$ & $\begin{array}{l}\text { Unfeasible. Cult: nonexistent; } \\
\mathrm{HS}_{\mathrm{L}} \text { : no data }\end{array}$ & Pop-Inc $\rightarrow$ Tour & $\begin{array}{l}\text { Feasible. Pop-Inc: data; Tour: } \\
\text { data }\end{array}$ \\
\hline $\mathrm{HS}_{\mathrm{L}} \rightarrow \mathrm{IHS}_{\mathrm{L}}$ & $\begin{array}{l}\text { Unfeasible. } \mathrm{HS}_{\mathrm{L}} \text { and } \mathrm{IHS}_{\mathrm{L}} \text { : no } \\
\text { data }\end{array}$ & SocEco $\rightarrow$ Tour & $\begin{array}{l}\text { Feasible. SocEco: existent; } \\
\text { Tour: data }\end{array}$ \\
\hline $\mathrm{IHS}_{\mathrm{L}} \rightarrow \operatorname{Agri}_{\mathrm{L}}$ & $\begin{array}{l}\text { Unfeasible. IHSL and Agri } \text { : } \\
\text { no data }\end{array}$ & Cult $\rightarrow$ Tour & $\begin{array}{l}\text { Unfeasible. Cult: nonexistent; } \\
\text { Tour: data }\end{array}$ \\
\hline Tech $\rightarrow$ Agri $_{\mathrm{L}}$ & $\begin{array}{l}\text { Unfeasible. Tech: nonexistent; } \\
\text { Agri }_{\mathrm{L}} \text { : no data }\end{array}$ & Tour $\rightarrow$ ProdCon & $\begin{array}{l}\text { Unfeasible. Tour: data; } \\
\text { ProdCon: no data }\end{array}$ \\
\hline $\operatorname{Agri}_{\mathrm{L}} \rightarrow$ LagSed & $\begin{array}{l}\text { Unfeasible. Agri }{ }_{\mathrm{L}} \text { and LagSed: } \\
\text { no data }\end{array}$ & PP-IMUSW $\rightarrow$ ProdCon & $\begin{array}{l}\text { Unfeasible. PP-IMUSW: } \\
\text { nonexistent; ProdCon: no data }\end{array}$ \\
\hline LagSed $\rightarrow$ PLoad $_{\mathrm{L}}$ & $\begin{array}{l}\text { Unfeasible. Agri } \\
\text { PLoad } \\
\text { L }: \text { no data }\end{array}$ & ProdCon $\rightarrow$ GSUW $_{\mathrm{L}}$ & $\begin{array}{l}\text { Unfeasible. ProdCon: no data; } \\
\text { GSUW }_{\mathrm{L}} \text { : no data }\end{array}$ \\
\hline $\operatorname{PLoad}_{\mathrm{L}} \rightarrow \operatorname{Sum}(\mathrm{N}, \mathrm{P})_{\mathrm{L}}$ & $\begin{array}{l}\text { Unfeasible. PLoad }{ }_{L} \text { and } \\
\text { Sum }(\mathrm{N}, \mathrm{P})_{\mathrm{L}}: \text { no data }\end{array}$ & Tech $\rightarrow$ GSUW $_{\mathrm{L}}$ & $\begin{array}{l}\text { Unfeasible. Tech: nonexistent; } \\
\text { GSUW }_{\mathrm{L}} \text { : no data }\end{array}$ \\
\hline $\mathrm{HS}_{\mathrm{L}} \rightarrow \mathrm{RHS}_{\mathrm{L}}$ & $\begin{array}{l}\text { Unfeasible. } \mathrm{HS}_{\mathrm{L}} \text { and } \mathrm{RHS}_{\mathrm{L}} \text { : } \\
\text { no data }\end{array}$ & Tour $\rightarrow$ CManRes & $\begin{array}{l}\text { Unfeasible. Tour: data; } \\
\text { CManRes: no data }\end{array}$ \\
\hline Cult $\rightarrow \mathrm{RHS}_{\mathrm{L}}$ & $\begin{array}{l}\text { Unfeasible. Cult: nonexistent; } \\
\mathrm{SS}_{\mathrm{L}} \text { : no data }\end{array}$ & SocEco $\rightarrow$ CManRes & $\begin{array}{l}\text { Unfeasible. SocEco: existent; } \\
\text { CManRes: no data }\end{array}$ \\
\hline $\mathrm{Tech} \rightarrow \mathrm{RHS}_{\mathrm{L}}$ & $\begin{array}{l}\text { Unfeasible. Tech: nonexistent; } \\
\text { RHS }_{L} \text { : no data }\end{array}$ & PP-CCMR $\rightarrow$ CManRes & $\begin{array}{l}\text { Unfeasible. PP-CCMR: } \\
\text { nonexistent; CManRes: no } \\
\text { data }\end{array}$ \\
\hline $\mathrm{Tech} \rightarrow \mathrm{SS}_{\mathrm{L}}$ & $\begin{array}{l}\text { Unfeasible. Tech: nonexistent; } \\
\mathrm{SS}_{\mathrm{L}} \text { : no data }\end{array}$ & CManRes $\rightarrow$ ManLoss & $\begin{array}{l}\text { Unfeasible. CManRes: no } \\
\text { data; ManLoss: no data }\end{array}$ \\
\hline $\mathrm{RHS}_{\mathrm{L}} \rightarrow \mathrm{SS}_{\mathrm{L}}$ & $\begin{array}{l}\text { Unfeasible. } \mathrm{RHS}_{\mathrm{L}} \text { and } \mathrm{SS}_{\mathrm{L}} \text { : no } \\
\text { data }\end{array}$ & ManLoss $\rightarrow$ RWFE & $\begin{array}{l}\text { Unfeasible. ManLoss: RWFE: } \\
\text { no data }\end{array}$ \\
\hline $\mathrm{SS}_{\mathrm{L}} \rightarrow$ LagSed & $\begin{array}{l}\text { Unfeasible. } \mathrm{SS}_{\mathrm{L}} \text { and LagSed: } \\
\text { no data }\end{array}$ & SolWas $_{\mathrm{L}} \rightarrow$ RWFE & $\begin{array}{l}\text { Unfeasible. SolWas }{ }_{L} \text { : no data; } \\
\text { RWFE: no data }\end{array}$ \\
\hline $\mathrm{IHS}_{\mathrm{L}} \rightarrow \mathrm{GSUW}_{\mathrm{L}}$ & $\begin{array}{l}\text { Unfeasible. } \mathrm{IHS}_{\mathrm{L}} \text { and } \mathrm{GSUW}_{\mathrm{L}} \text { : } \\
\text { no data }\end{array}$ & PP-RAP $\rightarrow$ AgriL & $\begin{array}{l}\text { Unfeasible. PP-RAP: } \\
\text { nonexistent; Agri }: \text { no data }\end{array}$ \\
\hline $\mathrm{RHS}_{\mathrm{L}} \rightarrow \mathrm{GSUW}_{\mathrm{L}}$ & $\begin{array}{l}\text { Unfeasible. } \text { RHS }_{L} \text { and } \\
\text { GSUW }_{L}: \text { no data }\end{array}$ & LagSed $\rightarrow$ NLoad $_{\mathrm{L}}$ & $\begin{array}{l}\text { Unfeasible. LagSed: no data; } \\
\text { NLoad }_{\text {L }} \text { no data }\end{array}$ \\
\hline GSUW $_{\mathrm{L}} \rightarrow$ SolWas $_{\mathrm{L}}$ & $\begin{array}{l}\text { Unfeasible. GSUW } \mathrm{L}_{\mathrm{L}} \text { and } \\
\text { SolWas }_{\mathrm{L}} \text { : no data }\end{array}$ & $\operatorname{NLoad}_{\mathrm{L}} \rightarrow \operatorname{Sum}(\mathrm{N}, \mathrm{P})_{\mathrm{L}}$ & $\begin{array}{l}\text { Unfeasible. } \text { NLoad }_{L}: \text { no data; } \\
\text { Sum }(N, P)_{L}: \text { no data }\end{array}$ \\
\hline SolWas $\rightarrow$ Sum $(\text { LSW })_{\mathrm{L}}$ & $\begin{array}{l}\text { Unfeasible. SolWas and Sum } \\
(\mathrm{LSW})_{\mathrm{L}}: \text { no data }\end{array}$ & PP-RFM $\rightarrow$ ManLoss & $\begin{array}{l}\text { Unfeasible. PP-RFM: } \\
\text { nonexistent; ManLoss: no data }\end{array}$ \\
\hline
\end{tabular}


Table 2. Relationships of the river pathway.

\begin{tabular}{|c|c|c|c|}
\hline Relationship & Observations & Relationship & Observations \\
\hline SocEco $\rightarrow$ RivInd & $\begin{array}{l}\text { Feasible. SocEco: existent; } \\
\text { RivInd existent. }\end{array}$ & RivSed $\rightarrow$ PLoad $_{R}$ & $\begin{array}{l}\text { Unfeasible. RivSed: no data; } \\
\text { PLoad }_{R} \text { : no data }\end{array}$ \\
\hline PP-IndCon $\rightarrow$ RivInd & $\begin{array}{l}\text { Unfeasible. PP-IndCon: } \\
\text { nonexistent; RivInd: existent }\end{array}$ & $\mathrm{PLoad} \rightarrow \operatorname{Sum}(\mathrm{N}, \mathrm{P})_{\mathrm{R}}$ & $\begin{array}{l}\text { Unfeasible. PLoad }{ }_{R}: \text { no data; } \\
\text { Sum }(N, P)_{R}: \text { no data }\end{array}$ \\
\hline Tech $\rightarrow$ RivInd & $\begin{array}{l}\text { Unfeasible. Tech: nonexistent; } \\
\text { RivInd: existent }\end{array}$ & $\mathrm{HS}_{\mathrm{R}} \rightarrow \mathrm{RHS}_{\mathrm{R}}$ & $\begin{array}{l}\text { Unfeasible. } \mathrm{HS}_{\mathrm{R}}: \text { no data; } \\
\mathrm{RHS}_{\mathrm{R}} \text { : no data }\end{array}$ \\
\hline RivInd $\rightarrow$ GSHWas $_{R}$ & $\begin{array}{l}\text { Unfeasible. RivInd: existent; } \\
\text { GSHWas }_{\mathrm{R}} \text { : no data }\end{array}$ & Cult $\rightarrow$ RHS $_{\mathrm{R}}$ & $\begin{array}{l}\text { Unfeasible. Cult: nonexistent; } \\
\text { RHS }_{\mathrm{R}} \text { : no data }\end{array}$ \\
\hline Tech $\rightarrow$ GSHWas $_{R}$ & $\begin{array}{l}\text { Unfeasible. Tech: nonexistent; } \\
\text { GSHWas }_{\mathrm{R}} \text { : no data }\end{array}$ & $\mathrm{RHS}_{\mathrm{R}} \rightarrow \mathrm{WTP}$ & $\begin{array}{l}\text { Unfeasible. } \text { RHS }_{\mathrm{R}} \text { : no data; } \\
\text { WTP: no data }\end{array}$ \\
\hline PP-SHW $\rightarrow$ GSHWas $_{\mathrm{R}}$ & $\begin{array}{l}\text { Unfeasible. PP-SHW: } \\
\text { nonexistent; GSHWas } \mathrm{R} \text { : no } \\
\text { data }\end{array}$ & $\mathrm{IHS}_{\mathrm{R}} \rightarrow \mathrm{SS}_{\mathrm{R}}$ & $\begin{array}{l}\text { Unfeasible. } \mathrm{IHS}_{\mathrm{R}} \text { : no data; } \\
\mathrm{SS}_{\mathrm{R}} \text { : no data }\end{array}$ \\
\hline GSUWas $\rightarrow$ LiqWas $_{R}$ & $\begin{array}{l}\text { Unfeasible. GSHWas }{ }_{\mathrm{R}} \text { no } \\
\text { data; LiqWas: no data }\end{array}$ & $\mathrm{Tech} \rightarrow \mathrm{SS}_{\mathrm{R}}$ & $\begin{array}{l}\text { Unfeasible. Tech: nonexistent; } \\
\mathrm{SS}_{\mathrm{R}} \text { : no data }\end{array}$ \\
\hline GSUWas $\rightarrow$ SolWas $_{R}$ & $\begin{array}{l}\text { Unfeasible. GSHWas }{ }_{R} \text { no } \\
\text { data; SolWas: no data }\end{array}$ & $\mathrm{SS}_{\mathrm{R}} \rightarrow$ RivSed & $\begin{array}{l}\text { Unfeasible. } \mathrm{SS}_{\mathrm{R}} \text { : no data; } \\
\text { RivSed: no data }\end{array}$ \\
\hline LiqWasR $\rightarrow \operatorname{Sum}(\text { LSW })_{\mathrm{R}}$ & $\begin{array}{l}\text { Unfeasible. LiqWas }{ }_{\mathrm{R}} \text { : no data; } \\
\text { Sum(LSW) })_{\mathrm{R}} \text { : no data }\end{array}$ & RivSed $\rightarrow$ NLoad $_{R}$ & $\begin{array}{l}\text { Unfeasible. RivSed: no data; } \\
\text { NLoad }_{\mathrm{R}} \text { : no data }\end{array}$ \\
\hline SolWasR $\rightarrow$ Sum $(\text { LSW })_{R}$ & $\begin{array}{l}\text { Unfeasible. SolWas }{ }_{R} \text { : no data; } \\
\text { Sum }(L S W)_{R}: \text { no data }\end{array}$ & $\operatorname{NLoad}_{R} \rightarrow \operatorname{Sum}(\mathrm{N}, \mathrm{P})_{\mathrm{R}}$ & $\begin{array}{l}\text { Unfeasible. } \text { NLoad }_{R} \text { : no data; } \\
\text { Sum }(N, P)_{R}: \text { no data }\end{array}$ \\
\hline $\operatorname{Sum}(\mathrm{LSW}) \mathrm{R} \rightarrow \operatorname{Sum}(\mathrm{N}, \mathrm{P})_{\mathrm{R}}$ & $\begin{array}{l}\text { Unfeasible. Sum }(\mathrm{LSW})_{\mathrm{R}} \text { : no } \\
\text { data; Sum }(\mathrm{N}, \mathrm{P})_{\mathrm{R}}\end{array}$ & PP-SHW $\rightarrow$ RivSed & $\begin{array}{l}\text { Unfeasible. PP-SHW: } \\
\text { nonexistent; RivSed: no data }\end{array}$ \\
\hline Pop-Inc $\rightarrow \mathrm{HS}_{\mathrm{R}}$ & $\begin{array}{l}\text { Unfeasible. Pop-Inc: no data; } \\
\mathrm{HS}_{\mathrm{R}} \text { : no data }\end{array}$ & $\mathrm{WTP} \rightarrow \mathrm{SS}_{\mathrm{R}}$ & $\begin{array}{l}\text { Unfeasible. WTP: no data; } \\
\text { SS } \text { : no data }\end{array}$ \\
\hline $\mathrm{PP}-\mathrm{RH} \rightarrow \mathrm{HS}_{\mathrm{R}}$ & $\begin{array}{l}\text { Unfeasible. PP-RHS: } \\
\text { nonexistent; HSR: no data }\end{array}$ & $\mathrm{PP}-\mathrm{WTP} \rightarrow \mathrm{WTP}$ & $\begin{array}{l}\text { Unfeasible. PP-WTP: existent; } \\
\text { WTP: no data }\end{array}$ \\
\hline $\mathrm{HS}_{\mathrm{R}} \rightarrow \mathrm{IHS}_{\mathrm{R}}$ & $\begin{array}{l}\text { Unfeasible. } \mathrm{HS}_{\mathrm{R}}: \text { no data; } \\
\mathrm{IHS}_{\mathrm{R}} \text { : no data }\end{array}$ & Tech $\rightarrow$ WTP & $\begin{array}{l}\text { Unfeasible. Tech: nonexistent; } \\
\text { WTP: no data }\end{array}$ \\
\hline Cult $\rightarrow \mathrm{IHS}_{\mathrm{R}}$ & $\begin{array}{l}\text { Unfeasible. Cult: nonexistent; } \\
\text { IHS }_{\mathrm{R}} \text { : no data }\end{array}$ & $\mathrm{RHS}_{\mathrm{R}} \rightarrow \mathrm{GSUWas}_{\mathrm{R}}$ & $\begin{array}{l}\text { Unfeasible. } \text { RHS }_{\mathrm{R}} \text { : no data; } \\
\text { GSUWas } \text { : no data }\end{array}$ \\
\hline $\mathrm{IHS}_{\mathrm{R}} \rightarrow$ Agri $_{\mathrm{R}}$ & $\begin{array}{l}\text { Unfeasible. } \mathrm{IHS}_{\mathrm{R}} \text { : no data; } \\
\text { Agri }{ }_{\mathrm{R}} \text { : no data }\end{array}$ & Tech $\rightarrow$ GSUWas $_{R}$ & $\begin{array}{l}\text { Unfeasible. Tech: nonexistent; } \\
\text { GSUWas }{ }_{\mathrm{R}} \text { no data }\end{array}$ \\
\hline SocEco $\rightarrow$ Agri $_{R}$ & $\begin{array}{l}\text { Unfeasible. SocEco: existent; } \\
\text { Agri }_{R} \text { : no data }\end{array}$ & PP-SUW $\rightarrow$ GSUWas $_{R}$ & $\begin{array}{l}\text { Unfeasible. PP-SUW: } \\
\text { nonexistent; GSUWas } \mathrm{R} \text { : no } \\
\text { data }\end{array}$ \\
\hline Cult $\rightarrow$ Agri $_{R}$ & $\begin{array}{l}\text { Unfeasible. Cult: nonexistent; } \\
\text { Agri }_{R} \text { : no data }\end{array}$ & $\mathrm{IHS}_{\mathrm{R}} \rightarrow \mathrm{GSUWas}_{\mathrm{R}}$ & $\begin{array}{l}\text { Unfeasible. IHSR: no data; } \\
\text { GSUWas }_{\mathrm{R}} \text { : no data }\end{array}$ \\
\hline Agri $_{R} \rightarrow$ RivSed & $\begin{array}{l}\text { Unfeasible. Agri }: \text { no data; } \\
\text { RivSed: no data }\end{array}$ & $\mathrm{SocEco} \rightarrow \mathrm{HS}_{\mathrm{R}}$ & $\begin{array}{l}\text { Unfeasible. SocEco: existent; } \\
\mathrm{HS}_{\mathrm{R}} \text { : no data }\end{array}$ \\
\hline
\end{tabular}

In conclusion: for a total of 78 relationships, the sum of both pathways, just $3 / 78$ (4\%) relationships were feasible. Therefore, $96 \%$ (75/78) of relationships were unfeasible due to nonexistent formal evidence of those affected factors or "no data" for the factors associated with quantifiable data. We can verify that Indirect Drivers-I play a very important role as shown in the next analysis: nine public policies were required; the environmental education programs were detected in six relationships; technological support was required in nine relationships. Thus, a total of 24 of the Indirect Drivers-1 related to public-policies, technological skills, and cultural factors were required, which represents $30 \%$ of the total 
relationships. Just $3 / 78$ relationships (4\%) that required quantifiable data could satisfy this requirement. We can conclude that, due to the fact that $96 \%$ of the relationships were unfeasible, then a formal adequate assessment is unable to be carried out, which seriously weakens the way towards the development of sustainable conditions of the Tres Palos Lagoon.

\subsection{An Analysis of Public Policies for the Tres Palos Coastal Lagoon That Hinder Its Sustainability}

Public policies need to address important problems that may exert influence on the cultural eutrophication processes. These problems are related to the management of urban solid wastes, the special handling of wastes, the human settlements around the lagoon and river, the agricultural practices around the lagoon and river, the wastewater treatment plants, tourism activities, and the environmental education programs, among the most important. We have reviewed the public policies related to these problems. This review aimed to corroborate which pertinent issues are regulated and to identify potential contradictions between national and municipality levels related to their purposes. For instance, at the municipal level, the management of urban solid waste is carried out by private companies, which contradicts regulation law at a national level. A similar situation takes place in the management of the special handling of wastes, for which an adequate technology should be used for the disposal to final sites; this is not the case.

Regarding human settlements around the lagoon and river: the problems persist, which are related to sewerage, drinking water, drainage, and housing tenure security. They represent the main issues raised by international regulations.

Regarding agricultural practices around the lagoon and river: due to the fact that the farmers around the lagoon and the river do not obtain big volumes of production, they do not receive the benefits established by the law, which are oriented to only favor agricultural communities. These benefits are the protection of their economic interests, the improvement of their products, and the management of their agricultural conditions, among others.

Regarding wastewater treatment plants (WWTPs): a national regulation exists, but it deals with chemical composition of treated wastewaters, without considering installation requirements and the adequate functioning of such plants. In the municipal of Acapulco, there are several WWTPs located on the banks of the river, but due to their malfunctioning, they may contaminate the waterbodies. Moreover, for strange reasons, municipal legislation related to the management of waterbodies is focused to a large extent on beach maintenance. Unfortunately, this legislation does not take care of coastal lagoons, despite their attraction for intensive tourist activity. As a matter of fact, a similar situation concerns tourism activities, where the regulation is more concerned with attracting more tourists, but without taking into consideration plans to motivate care for the environment. Therefore, environmental education programs are current issues that urgently need to be taken into account in a permanent way. It is worth mentioning that this objective exists, but it is yet to be implemented.

Suggestions for the Short Term Aimed at Improving the Sustainability Conditions of the Coastal Lagoon

The preceding analysis, the results shown in Section 3.5, and the pathways depicted in Figure 2 are important sources of information to support the decision-making process aimed at selecting actions to improve sustainability conditions of the coastal lagoon. As shown before, the adequate implementation of actions related to public policies, technological skills, and cultural factors is very important for achieving sustainability conditions in the coastal lagoon. Using the pathways shown in Figure 2, we can identify nodes related to human settlements close to the lagoon and river, as well as tourism and agricultural practices related to the lagoon and river, as key factors that exert important influence in the eutrophication process.

Based on these sources of information, we suggest carrying out a formal performance evaluation of two factors: (1) the public policies already generated, and, in some cases, 
already implemented, related to human settlements, agricultural practices, and tourism; (2) the technological implementations related to wastewater treatment plants, the management urban waste, and the special handling of waste. In addition, we emphasize the implementation of environmental education programs for both schools and the general public.

3.7. Disadvantages and Advantages in the Use of Multifactorial Approaches for the Study of the Cultural Eutrophication Process

\subsubsection{Disadvantages}

Traditionally, the assessment of the quality of waterbodies, such as coastal lagoons, is focused on the evaluation of their trophic state by using documented methods based on measuring the quantities of nutrients found in the water body. From the point of view of the cultural eutrophication process, this method is quite limited, because this process involves multiple factors associated with human activities, which are the main causes or influences that affect the cultural eutrophication process and consequently the trophic changes of waterbodies. These human activities are related to diverse factors associated with indirect drivers belonging to different domains, such as population increase, sociopolitical, socioeconomic, technological, and cultural factors. Thus, the cultural eutrophication process represents an important problem that must be addressed within multifactorial contexts. Otherwise, the intention to attain sustainable conditions will definitely fail. However, an important disadvantage related to the development of models of multifactorial interactions is that they bring about complex systems, which are usually hard to understand and, consequently, very hard to assess.

\subsubsection{Advantages}

Based on the fact that we have developed models and methods to facilitate both the understanding and the assessment of the complexity related to the multifactorial interactions involved in the cultural eutrophication processes, we show below the following advantages:

(i) We are able to identify what relationships, within the network of relationships, are causing damage to the eutrophication process and, even more, what factors are involved.

(ii) We are able to identify those pathways that are causing the most important damage.

(iii) We are able to distinguish whether the damages are related to demographic, sociopolitical, socioeconomic, technological or cultural factors. Thus, these factors will not be overlooked in the analysis aimed at identifying which factors cause or influence the eutrophication process and damage the trophic state.

- We are able to identify what data, information, and resources are lacking or missing, which make unfeasible the evaluation of relationships between factors involved in the pathways.

- The improvement of the understanding and assessment of the cultural eutrophication process will support the decision-making process to select adequate management actions.

- Multifactorial analyses and assessments are very important tools to pave the way towards the sustainability of coastal lagoons.

\subsection{On the Advantages of Building Pathways by Using the New Classification Related to Indirect Drivers and Direct Drivers}

The construction of pathways, represented by sequences of relationships to link indirect drivers with direct drivers that affect the trophic state of the lagoon, was a key concept to facilitate the analysis of the network that represents the multifactorial eutrophication process (EP). Without doubt, the reclassification of indirect and direct drivers (see Figure 1) facilitated the construction of the pathways. Two pathways associated with the EP have been built: (1) the lagoon pathway that links indirect drivers to direct drivers through relationships associated with the lagoon that may exert effects or influence the quantities of nutrients disposed of into the lagoon; (2) the river pathway that links indirect drivers 
with direct drivers through relationships associated with the river that may exert effects or influence the quantities of nutrients disposed of into the lagoon.

Another advantage of building pathways is that a pathway can be divided into subpathways, thus, facilitating even more the analysis of relationships. For example, the river pathway depicted in Figure 2 may be divided into the three following sub-pathways:

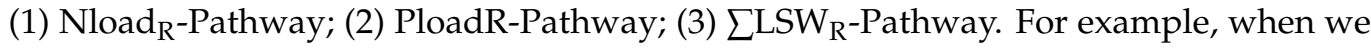
analyze the Nload $_{R}$-Pathway and the PloadR-Pathway, we can denote the importance of the river industry and agriculture practices at the level of the river for the load of nitrogen and phosphorous into the lagoon. Meanwhile, the analysis of the $\sum L S W_{R}-$ Pathway shows that the contribution of human settlements (regular and irregular) to the generation of solid urban waste at the level of the river is very significant for the solid and liquid waste to be disposed of into the lagoon.

\subsection{The Coastal Lagoon State Related to Human Settlements and Mangroves: From 1981 to 2015}

The Tres Palos coastal lagoon is located $25 \mathrm{~km}$ to the southeast of Acapulco, Guerrero. It belongs to the Hydrological-Administrative Region No. 19 Costa Chica. The Tres Palos coastal lagoon measures 15 kilometers long and 5.5 kilometers wide with a depth between 5 and 8 meters. The Sabana river feeds the lagoon with water, which receives constant urban waste discharges, thus causing changes in the trophic state of the lagoon. The lagoon joins the sea through a meandering channel of $12 \mathrm{~km}$ that ends in the town of Barra Vieja.

The purpose of Figure 4 is to show the changes of human settlements around the river and the lagoon (stained red) from 1981 to 2015 (35 years), as well as the decline of mangroves located at the bottom extreme southeast of the lagoon, stained green. As shown in the preceding evaluations of relationships, the lack of data hinders a quantitative assessment of human settlements around the lagoon and the river, and of the assessment of mangrove loss. However, we can visually confirm that the increase in human settlements around the lagoon and the river was very important between 1981 and 2005 (25 years). The difference between 2005 and 2015 is also remarkable.
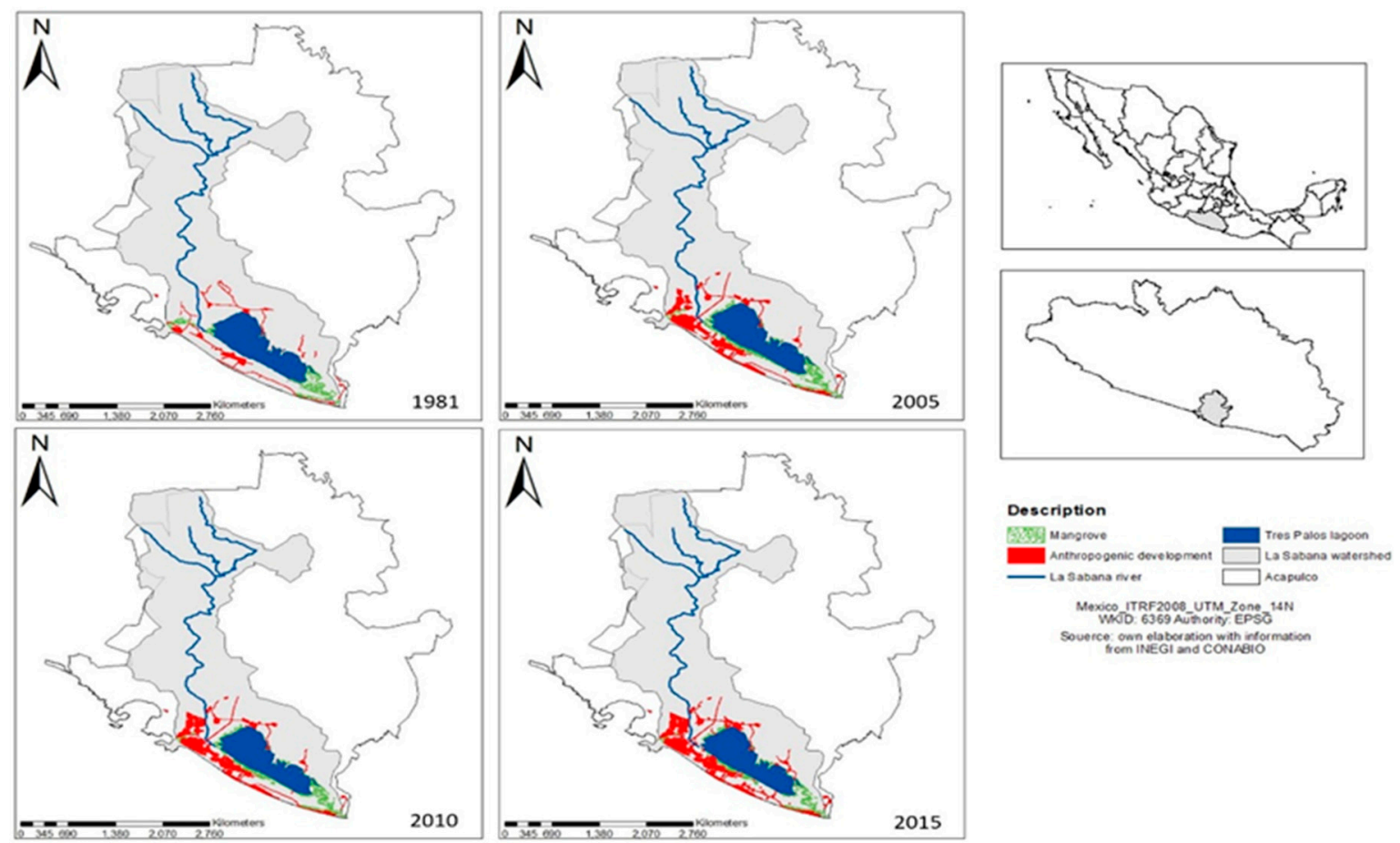

Figure 4. Increase in human settlements around the lagoon and decline of mangroves: 1981 to 2015.

The mangrove decline is also notable between 1981 and 2015, which is depicted by the dense stain at the bottom extreme southeast of the lagoon (in green) in 1981, compared 
with the sparse stain in 2015. Reforestation actions were implemented in mangrove areas where it was being lost and not used for any other land use. However, from 2000 to date, part of the mangrove has been dredged frequently to establish a new tourism area, thus resulting in mangrove loss.

\section{Conclusions}

We have argued in this work that the cultural eutrophication process should be addressed by multifactorial approaches, where the anthropogenic activities play an important role. We have highlighted that the development of models based on multifactorial approaches represents a big challenge because they lead to complex systems that are usually hard to understand and, consequently, very hard to assess.

In this work, we have addressed the understanding of complex systems derived from the multifactorial interactions and how a better understanding of such systems supports and facilitates the assessment of the cultural eutrophication processes, which damages the trophic state of the coastal lagoon.

We have reclassified the indirect and direct drivers involved in the cultural eutrophication processes. Such reclassification has facilitated the construction of pathways to link indirect drivers with direct drivers, where the former factors are associated with abstract concepts such as demographic, socioeconomic, sociopolitical, technological, and cultural factors. Meanwhile, the latter factors are associated with quantifiable accumulations of nutrients that change the trophic state of the lagoon.

The pathways were assessed through their sequence of relationships. In such a way, we have aimed at establishing whether the evaluation of pathways was feasible or unfeasible, carried out through their relationships. Thus, the basic elements to be evaluated were the relationships, which are composed of an effector and a receptor factor. This method facilitated the evaluation of pathways. The feasibility of the evaluation of two pathways has been carried out: the lagoon and the river pathways.

We conclude that due to the fact that $96 \%$ (75/78) of the relationships are unfeasible, due to nonexistent key indirect drivers (public policy, technological support and environmental education programs) and lacking data of quantifiable factors, then an assessment of the eutrophication process is not possible to be carried out, thus seriously weakening the possibility of paving the way towards the development of sustainable conditions for the Tres Palos coastal lagoon. We can reason as follows: if the assessment of a system (complex or not) is unable to be performed, then the decision-making process to select adequate environmental management actions is weak, which in turn affects the goal of reaching sustainable conditions.

Unfortunately, similar situations are characteristic of developing countries: missing data and the lack of public policies, technological skills and environmental cultural programs, which are essential aspects for supporting sustainable conditions for coastal lagoons. The lack of, or missing or imprecise, data, in combination with problematic public policies, means that technological skills and environmental cultural programs are relevant obstacles for achieving desired sustainability.

The methods proposed in this work can be replicated to study the feasibility of the sustainability of other coastal lagoons.

Author Contributions: Conceptualization, F.R.-Q., and A.I.C.-J.; methodology, F.R.-Q., and A.I.C.-J.; validation, F.R.-Q., A.I.C.-J., A.L.J.-L., M.R.-U., J.L.R.-A.; formal analysis, F.R.-Q., A.I.C.-J., A.L.J.-L., M.R.-U., J.L.R.-A., A.L.R.-H.; investigation, F.R.-Q., A.I.C.-J.; writing-original draft preparation, F.R.-Q., A.I.C.-J.; writing-review and editing, F.R.-Q., A.I.C.-J. All authors have read and agreed to the published version of the manuscript.

Funding: This research received no external funding.

Acknowledgments: We thank Rosalind Pearson for her comments and suggestions that improved our manuscript. We also thank reviewers for their valuable comments and suggestions to improve the manuscript. 
Conflicts of Interest: The authors declare no conflict of interest.

\section{References}

1. Kennish, M.J.; Paerl, H. Coastal Lagoons: Critical Habitats of Environmental Change; Kennish, M.J., Paerl, H.W., Eds.; Marine Science Series; CRC Press: Boca Raton, FL, USA, 2010; pp. 1-16.

2. Barbier, E.B.; Hacker, S.D.; Kennedy, C.; Koch, E.W.; Stier, A.C.; Silliman, B.R. The value of estuarine and coastal ecosystem services. Ecol. Monogr. 2011, 81, 169-193. [CrossRef]

3. Costanza, R.; d'Arge, R.; de Groot, R.; Farber, S.; Grasso, M.; Hannon, B.; Limburg, K.; Naeem, S.; O’Neill, R.V.; Paruelo, J.; et al. The value of the world's ecosystem services and natural capital. Nature 1997, 387, 253-260. [CrossRef]

4. Costanza, R.; De Groot, R.; Sutton, P.C.; Van Der Ploeg, S.; Anderson, S.J.; Kubiszewski, I.; Farber, S.; Turner, R.K. Changes in the global value of ecosystem services. Glob. Environ. Chang. 2014, 26, 152-158. [CrossRef]

5. Inda, H.; García-Rodríguez, F.; Del Puerto, L.; Stutz, S.; Figueira, R.C.L.; Ferreira, P.A.D.L.; Mazzeo, N. Discriminating between natural and human-induced shifts in a shallow coastal lagoon: A multidisciplinary approach. Anthropocene 2016, 16, 1-15. [CrossRef]

6. Tavares, D.C.; Guadagnin, D.L.; De Moura, J.F.; Siciliano, S.; Merico, A. Environmental and anthropogenic factors structuring waterbird habitats of tropical coastal lagoons: Implications for management. Biol. Conserv. 2015, 186, 12-21. [CrossRef]

7. Chin, A.; Florsheim, J.L.; Wohl, E.; Collins, B.D. Feedbacks in Human-Landscape Systems. Environ. Manag. 2013, 53, 28-41. [CrossRef]

8. Pérez-Ruzafa, Á.; Marcos, C.; Pérez-Ruzafa, M. Recent advances in coastal lagoons ecology: Evolving old ideas and assump-tions. Transit. Waters Bull. 2011, 5, 50-74. [CrossRef]

9. Ramos-Quintana, F.; Sotelo-Nava, H.; Saldarriaga-Noreña, H.A.; Tovar-Sánchez, E. Assessing the Environmental Quality Resulting from Damages to Human-Nature Interactions Caused by Population Increase: A Systems Thinking Approach. Sustainability 2019, 11, 1957. [CrossRef]

10. Skoulikidis, N. The environmental state of rivers in the Balkans-A review within the DPSIR framework. Sci. Total. Environ. 2009, 407, 2501-2516. [CrossRef]

11. Hoornweg, D.; Bhada-Tata, P.; Kennedy, C.W. Environment: Waste production must peak this century. Nature 2013, 502, 615-617. [CrossRef]

12. Dyson, B.; Chang, N.-B. Forecasting municipal solid waste generation in a fast-growing urban region with system dynamics modeling. Waste Manag. 2005, 25, 669-679. [CrossRef] [PubMed]

13. The World Bank. What a Waste. 2018. Available online: https://openknowledge.worldbank.org/handle/10986/30317 (accessed on 6 August 2020).

14. Senzige, J.P. Modelling the Effects of Population Dynamics on Solid Waste Generation and Treatment. Sci. J. Appl. Math. Stat. 2016, 4, 141. [CrossRef]

15. Manaf, L.A.; Abu Samah, M.A.; Zukki, N.I.M. Municipal solid waste management in Malaysia: Practices and challenges. Waste Manag. 2009, 29, 2902-2906. [CrossRef]

16. Minghua, Z.; Xiumin, F.; Rovetta, A.; Qichang, H.; Vicentini, F.; Bingkai, L.; Giusti, A.; Yi, L. Municipal solid waste management in Pudong New Area, China. Waste Manag. 2009, 29, 1227-1233. [CrossRef]

17. Bricker, S.B.; Ferreira, J.; Simas, T. An integrated methodology for assessment of estuarine trophic status. Ecol. Model. 2003, 169, 39-60. [CrossRef]

18. Newton, A.; Icely, J.; Falcao, M.; Nobre, A.M.; Nunes, J.P.; Ferreira, J.; Vale, C. Evaluation of eutrophication in the Ria Formosa coastal lagoon, Portugal. Cont. Shelf Res. 2003, 23, 1945-1961. [CrossRef]

19. Smith, V.H.; Schindler, D.W. Eutrophication science: Where do we go from here? Trends Ecol. Evol. 2009, 24, 201-207. [CrossRef]

20. Cotovicz, L.C.; Brandini, N.; Knoppers, B.A.; Mizerkowski, B.D.; Sterza, J.M.; Ovalle, A.R.C.; Medeiros, P.R.P. Assessment of the trophic status of four coastal lagoons and one estuarine delta, eastern Brazil. Environ. Monit. Assess. 2012, 185, $3297-3311$. [CrossRef]

21. Silveira, J.A.H.; Ramírez-Ramírez, J. Salinity and nutrients in the coastal lagoons of Yucatan, Mexico. SIL Proc. 1922-2010 1995, 26, 1473-1478. [CrossRef]

22. Esteves, F.A.; Caliman, A.; Santangelo, J.M.; Guarient, R.D.; Farjalla, V.F.; Brozelli, R.L. Neotripical coastal lagoons: An ap-praisal of their biodiversity, functioning, threats and conservation management. Braz. J. Biol. 2008, 68, 967-981. [CrossRef]

23. Otu, M.K.; Ramlal, P.; Wilkinson, P.; Hall, R.I.; Hecky, R.E. Paleolimnological evidence of the effects of recent cultural eutrophication during the last 200years in Lake Malawi, East Africa. J. Great Lakes Res. 2011, 37, 61-74. [CrossRef]

24. Thevenon, F.; Adatte, T.; Wildi, W.; Poté, J. Antibiotic resistant bacteria/genes dissemination in lacustrine sediments highly increased following cultural eutrophication of Lake Geneva (Switzerland). Chemosphere 2012, 86, 468-476. [CrossRef] [PubMed]

25. Chislock, M.F.; Doster, E.; Zitomer, R.A.; Wilson, A.E. Eutrophication: Causes, Consequences, and Controls in Aquatic Eco-systems. Nat. Educ. Knowl. 2013, 4, 10.

26. Cotovicz, L.C., Jr.; Knoppers, B.A.; Brandini, N.; Santos, S.J.C.; Abril, G. A strong $\mathrm{CO}_{2}$ sink enhanced by eutrophication in a tropical coastal embayment (Guanabara Bay, Rio de Janeiro, Brazil). Biogeosciences 2015, 12, 6125-6146. [CrossRef]

27. Van Rijssel, J.C.; Hecky, R.E.; Kishe-Machumu, M.A.; Witte, F. Changing ecology of Lake Victoria cichlids and their environment: Evidence from C13 and N15 analyses. Hydrobiologia 2016, 791, 175-191. [CrossRef] 
28. Haas, M.; Baumann, F.; Castella, D.; Haghipour, N.; Reusch, A.; Strasser, M.; Eglinton, T.I.; Dubois, N. Roman-driven cultural eutrophication of Lake Murten, Switzerland. Earth Planet. Sci. Lett. 2019, 505, 110-117. [CrossRef]

29. Fielding, J.J.; Croudace, I.W.; Kemp, A.E.; Pearce, R.B.; Cotterill, C.J.; Langdon, P.; Avery, R. Tracing lake pollution, eutrophication and partial recovery from the sediments of Windermere, UK, using geochemistry and sediment microfabrics. Sci. Total. Environ. 2020, 722, 137745. [CrossRef]

30. Dillon, P.; Kirchner, W. The effects of geology and land use on the export of phosphorus from watersheds. Water Res. 1975, 9 , 135-148. [CrossRef]

31. Carpenter, S.R. Eutrophication of aquatic ecosystems: Bistability and soil phosphorus. Proc. Natl. Acad. Sci. USA 2005, 102, 10002-10005. [CrossRef]

32. Granat, L. Deposition of Nitrate and Ammonium from the Atmosphere to the Baltic Sea. Ecol. Stud. 2001, 148, 133-148. [CrossRef]

33. Lo, W.-T.; Purcell, J.E.; Hung, J.-J.; Su, H.-M.; Hsu, P.-K. Enhancement of jellyfish (Aurelia aurita) populations by extensive aquaculture rafts in a coastal lagoon in Taiwan. ICES J. Mar. Sci. 2008, 65, 453-461. [CrossRef]

34. La Notte, A.A.; Turvani, M.; Giaccaria, S. Economic valuation of ecosystem services at local level for policy makers and planners. The case of the island of St. Erasmo in the Lagoon of Venice. Environ. Econ. 2001, 2, 87-103.

35. Rova, S.; Pranovi, F.; Müller, F. Provision of ecosystem services in the lagoon of Venice (Italy): An initial spatial assessment. Ecohydrol. Hydrobiol. 2015, 15, 13-25. [CrossRef]

36. O'Higgins, T.; Nogueira, A.A.; Lillebø, A.I. A simple spatial typology for assessment of complex coastal ecosystem services across multiple scales. Sci. Total. Environ. 2019, 649, 1452-1466. [CrossRef] [PubMed]

37. Malinga, R.; Gordon, L.J.; Jewitt, G.; Lindborg, R. Mapping ecosystem services across scales and continents-A review. Ecosyst. Serv. 2015, 13, 57-63. [CrossRef]

38. Vilardy, S.P.; González, J.A.; Martín-López, B.; Montes, C. Relationships between hydrological regime and ecosystem services supply in a Caribbean coastal wetland: A social-ecological approach. Hydrol. Sci. J. 2011, 56, 1423-1435. [CrossRef]

39. Basset, A.; Elliott, M.; West, R.; Wilson, J.G. Estuarine and lagoon biodiversity and their natural goods and services. Estuarine Coast. Shelf Sci. 2013, 132, 1-4. [CrossRef]

40. Lillebø, A.I.; Somma, F.; Norén, K.; Gonçalves, J.; Alves, M.F.; Ballarini, E.; Bentes, L.; Bielecka, M.; Chubarenko, B.V.; Heise, S.; et al. Assessment of marine ecosystem services indicators: Experiences and lessons learned from 14 European case studies. Integr. Environ. Assess. Manag. 2016, 12, 726-734. [CrossRef]

41. Aldana-Domínguez, J.; Montes, C.; Martínez, M.; Medina, N.; Hahn, J.; Duque, M. Biodiversity and Ecosystem Services Knowledge in the Colombian Caribbean. Trop. Conserv. Sci. 2017, 10, 1-41. [CrossRef]

42. Velasco, A.M.; Pérez-Ruzafa, A.; Martínez-Paz, J.M.; Marcos, C. Ecosystem services and main environmental risks in a coastal lagoon (Mar Menor, Murcia, SE Spain): The public perception. J. Nat. Conserv. 2018, 43, 180-189. [CrossRef]

43. Galloway, J.N.; Dentener, F.J.; Capone, D.G.; Boyer, E.W.; Howarth, R.W.; Seitzinger, S.P.; Asner, G.P.; Cleveland, C.C.; Green, P.A.; Holland, E.A.; et al. Nitrogen Cycles: Past, Present, and Future. Biogeochemistry 2004, 70, 153-226. [CrossRef]

44. Orabi, O.H.; Osman, M.F. Evaluation of Some Pollution at Manzala Lagoon: Special Reference to Medical Importance of Mollusca in Egypt. J. Environ. Anal. Toxicol. 2015, 5, 311. [CrossRef]

45. Ruiz-Ruiz, T.M.; Arreola-Lizárraga, J.A.; Morquecho, L.; Mendoza-Salgado, R.A.; Martínez-López, A.; Méndez-Rodríguez, L.C.; Enríquez-Flores, J. Assessment of eutrophication in a subtropical lagoon in the Gulf of California. Aquat. Ecosyst. Health Manag. 2016, 19, 382-392. [CrossRef]

46. Souchu, P.; Bec, B.; Smith, V.H.; Laugier, T.; Fiandrino, A.; Benau, L.; Orsoni, V.; Collos, Y.; Vaquer, A. Patterns in nutrient limitation and chlorophyll a along an anthropogenic eutrophication gradient in French Mediterranean coastal lagoons. Can. J. Fish. Aquat. Sci. 2010, 67, 743-753. [CrossRef]

47. Dodds, W.K.; Cole, J.J. Expanding the concept of trophic state in aquatic ecosystems: It's not just the autotrophs. Aquat. Sci. 2007, 69, 427-439. [CrossRef]

48. Dodds, W.K. Trophic state, eutrophication and nutrient criteria in streams. Trends Ecol. Evol. 2007, 22, 669-676. [CrossRef]

49. Kormas, K.A.; Nicolaidou, A.; Reizopoulou, S. Temporal Variations of Nutrients, -Chlorophyll a and Particulate Matter in Three Coastal Lagoons of Amvrakikos Gulf (Ionian Sea, Greece). Mar. Ecol. 2001, 22, 201-213. [CrossRef]

50. Smith, V.H.; Joye, S.B.; Howarth, R.W. Eutrophication of freshwater and marine ecosystems. Limnol. Oceanogr. 2006, 51, 351-355. [CrossRef]

51. Ganguly, D.; Patra, S.; Muduli, P.R.; Vardhan, K.V.; Abhilash, K.R.; Robin, R.S.; Subramanian, B.R. Influence of nutrient input on the trophic state of a tropical brackish water lagoon. J. Earth Syst. Sci. 2015, 124, 1005-1017. [CrossRef]

52. Rodellas, V.; Stieglitz, T.C.; Andrisoa, A.; Cook, P.G.; Raimbault, P.; Tamborski, J.J.; Van Beek, P.; Radakovitch, O. Groundwaterdriven nutrient inputs to coastal lagoons: The relevance of lagoon water recirculation as a conveyor of dissolved nutrients. Sci. Total. Environ. 2018, 642, 764-780. [CrossRef]

53. Lewison, R.L.; Rudd, M.A.; Al-Hayek, W.; Baldwin, C.; Beger, M.; Lieske, S.N.; Jones, C.; Satumanatpan, S.; Junchompoo, C.; Hines, E. How the DPSIR framework can be used for structuring problems and facilitating empirical research in coastal systems. Environ. Sci. Policy 2016, 56, 110-119. [CrossRef]

54. OECD. Towards Sustainable Development: Environmental Indicators; Organization for Economic Cooperation and Development: Paris, France, 1998. 
55. Carr, E.R.; Wingard, P.M.; Yorty, S.C.; Thompson, M.C.; Jensen, N.K.; Roberson, J. Applying DPSIR to sustainable development. Int. J. Sustain. Dev. World Ecol. 2007, 14, 543-555. [CrossRef]

56. Bidone, E.D.; De Lacerda, L.D. The use of DPSIR framework to evaluate sustainability in coastal areas. Case study: Guanabara Bay basin, Rio de Janeiro, Brazil. Reg. Environ. Chang. 2004, 4, 5-16. [CrossRef]

57. Sun, S.; Wang, Y.; Liu, J.; Cai, H.; Wu, P.; Geng, Q.; Xu, L. Sustainability assessment of regional water resources under the DPSIR framework. J. Hydrol. 2016, 532, 140-148. [CrossRef]

58. Atkins, J.P.; Burdon, D.; Elliott, M.; Gregory, A.J. Management of the marine environment: Integrating ecosystem services and societal benefits with the DPSIR framework in a systems approach. Mar. Pollut. Bull. 2011, 62, 215-226. [CrossRef] [PubMed]

59. Gari, S.R.; Newton, A.; Icely, J. A review of the application and evolution of the DPSIR framework with an emphasis on coastal social-ecological systems. Ocean Coast. Manag. 2015, 103, 63-77. [CrossRef]

60. Azevedo, A.; Sousa, A.I.; e Silva, J.D.L.; Dias, J.M.; Lillebø, A.I. Application of the generic DPSIR framework to seagrass communities of Ria de Aveiro: A better understanding of this coastal lagoon. J. Coast. Res. 2013, 65, 19-24. [CrossRef]

61. Dolbeth, M.; Stålnacke, P.; Alves, F.L.; Sousa, L.P.; Gooch, G.D.; Khokhlov, V.; Tuchkovenko, Y.; Lloret, J.; Bielecka, M.; Różyński, G.; et al. An integrated Pan-European perspective on coastal Lagoons management through a mosaic-DPSIR approach. Sci. Rep. 2016, 6, 19400. [CrossRef]

62. Niemeijer, D.; De Groot, R.S. Framing environmental indicators: Moving from causal chains to causal networks. Environ. Dev. Sustain. 2006, 10, 89-106. [CrossRef]

63. Tscherning, K.; Helming, K.; Krippner, B.; Sieber, S.; Paloma, S.G.Y. Does research applying the DPSIR framework support decision making? Land Use Policy 2012, 29, 102-110. [CrossRef]

64. Carpenter, S.R.; DeFries, R.; Dietz, T.; Mooney, H.A.; Polasky, S.; Reid, W.V.; Scholes, R.J. ECOLOGY: Enhanced: Millennium Ecosystem Assessment: Research Needs. Science 2006, 314, 257-258. [CrossRef] [PubMed]

65. Carpenter, S.R.; Mooney, H.A.; Perrings, C.; Reid, W.V.; Sarukhan, J.; Scholes, R.J.; Whyte, A.; Agard, J.; Capistrano, D.; DeFries, R.S.; et al. Science for managing ecosystem services: Beyond the Millennium Ecosystem Assessment. Proc. Natl. Acad. Sci. USA 2009, 106, 1305-1312. [CrossRef] [PubMed]

66. IPBES. Summary for Policymakers of the Global Assessment Report on Biodiversity and Ecosystem Services of the Intergovernmental Science-Policy Platform on Biodiversity and Ecosystem Services; Díaz, S., Settele, J., Brondízio, E.S., Ngo, H.T., Guèze, M., Agard, J., Arneth, A., Balvanera, P., Brauman, K.A., Butchart, S.H.M., et al., Eds.; IPBES Secretariat: Bonn, Germany, 2009; 56p. 